\title{
Opetustapahtuman tutkimus aikuiskasvatuksessa
}

\author{
Joitakin ensi yrityksiä ja niiden tuloksia ${ }^{1}$
}

\begin{abstract}
Siebert, Horst, 1983. Opetustapahtuman tutkimus aikuiskasvatuksessa. Aikuiskasvatus 3, 4, 148-154. - Artikkeli on katsaus Saksan liittotasavallassa suoritettuihin opetustapahtumaan kohdistuneisiin tutkimuksiin. Artikkelissa käsitellään tekijöitä, jotka ovat olleet syinä tutkimusten epäonnistumisiin ja tulosten vähämerkityksellisyyteen erityisesti käytännön aikuiskasvatuksen kannalta. Lopuksi esitellään aikuisopetuksen tutkimustuloksia sekä toimenpiteitä, joilla tutkimusten toteutusta voidaan kehittää.
\end{abstract}

\begin{abstract}
Usein on valitettu sitä, ettei aikuiskasvatuksessa ole olemassa riittävästi luotettavaa tietoa opetustapahtumasta, eikä varsinkaan itse opetus- ja oppimisprosesseista. Monet yritykset koota tätä tietoa ovat jääneet suhteellisen tuloksettomiksi. Tiedon puutteeseen on useitakin syitä. Opetuksen tutkiminen on tuskin mahdollista jos se tapahtuu erillään siitä, mitä opetuksessa todella tapahtuu; opetuksen havainnointi on siis tarpeen. Tämä havainnointi voi toteutua joko siten, että tutkijat itse osallistuvat opetukseen tai siten, että tutkitaan audiovisuaalisesti taltioitua opetusta. Kummassakin tapauksessa tutkimus vaikuttaa opetustilanteeseen ja aiheuttaa siinä muutosta. Näin käy tietenkin myös havainnoitaessa opetusta kouluissa; aikuiskasvatuksessa vaikutus saattaa olla vielä merkittävämpi, sillä sekä henkilökunta että opiskelijat osallistuvat opetukseen "vapaaehtoisesti" ja useat heistä suhtautuvat havainnointiin epäilevästi, koska heillä on ollut kielteisiä kokemuksia kontrollista työpaikallaan tai, kun kyseessä on päätoiminen henkilökunta, harjoitteluaikanaan. Havainnointiin suhtaudutaan tällä tavoin erityisesti silloin kun ei tiedetä, keitä havainnoijat ovat, mitä havainnoidaan ja mihin tarkoitukseen saatua aineistoa tutkimuksessa käytetään. Aikuisoppilaitosten johto ei voi myöskään ottaa sitä ris-

1Julkaistu vuonna 1981 englanninkielisenä eripainoksena Saksan Liittotasavallassa Institute for Scientific Co-Operation -toimesta.
\end{abstract}

kiä, että havainnointi aiheuttaa suhteettoman paljon häiriötä, koska se saattaa johtaa opiskelijamäärän vähenemiseen tutkimuksen kohteena olevalla kurssilla. Niin kauan kuin aikuisoppilaitokset toimivat toisiinsa nähden kilpailuasemassa, ne ovat myöskin taipuvaisia pelkäämään, että havainnointi tuo mahdollisesti mukanaan epäedullisia tutkimustuloksia ja ne voivat vaikuttaa kielteisesti aikuiskasvatusviranomaisiin. Niin kauan kuin aikuiskasvatusta ei ole organisoitu julkisen kasvatusjärjestelmän yhdeksi osaksi, tämän koulutussektorin täytyy jatkuvasti osoittaa olevansa sekä tarpeellinen että tehokas - ja on myönnettävä, että viime aikoina sama vaatimus on koskenut myös koulujärjestelmää. Tässä mielessä tutkimuskohde on siis varsin vaikea ja arkaluontoinen. Aikuiskasvatusta on yhä vaikeampi ja vaikeampi päästä tutkimaan, koska sen parissa työskentelevät ovat omaksuneet itsestään ammatin harjoittajina korostuneesti sellaisen käsityksen, jonka mukaan heidän on puolustettava omia tutkimuksen vastaisia intressejään tai julistettava tutkimus ko. alan kannalta epäolennaiseksi (vrt. Tietgens 1977, 12).

Monien aikuiskasvattajien haluttomuus sallia antamansa opetuksen havainnointi tai edes käsitellä siihen liittyviä kysymyksiä perustuu usein huonoihin kokemuksiin tutkijaryhmistä ja yksittäisistä tutkijoista. Länsi-Saksan opistopäivillä 1976 keskusteltiin yhteistyön ja kommunikaation epäonnistumisista. 
Tällöin kävi ilmi, että

a) useat laitokset ja organisaatiot katsovat, että niillä on liiaksi työtä lomakkeista ja kyselyistä, että

b) tutkimuksen alullepanijoista, lähtökohdista ja päämääristä ei useinkaan olla selvillä,

c) kysymykset ovat usein luonteeltaan sellaisia, että niillä tuntuu olevan vain vähän merkitystä itse kasvatuskäytännössä,

d) on varsin harvinaista, että tutkimus on suunniteltu (tai ongelmanasettelu suoritettu) yhteistyössä aikuiskasvattajien kanssa

e) tutkijoita näyttää kiinnostavan varsin vähän, millaisissa olosuhteissa itse opetustyö tapahtuu,

f) monet kyselykaavakkeet ja projektisuunnitelmat osoittavat huonoa aikuiskavatusympäristön tuntemusta

g) tutkittavien ongelmien monitahoisuudesta johtuen eivät 'kyllä' ja 'ei' riitä vastausvaihtoehdoiksi,

h) usein aikuiskasvatuksen piirissä työskentelevät ja heidän oppilaansa pakotetaan rooliin, jossa heidän ainoa tehtävänsä tutkimuskohteina on vahvistaa tutkijoiden olettamusten paikkansapitävyys,

i) tutkimuksen anonyymistä välineestä, kyselylomakkeesta, ei pidetä,

j) saatua tietoa tutkittaessa huomio kiintyy vain harvoin niihin todellisiin olosuhteisiin, joissa opetus tapahtuu ja sen institutionaaliseen viitekehykseen; sen sijaan opetusta mitataan shemaattisesti ihannenormein,

k) tutkimuksen tulokset saatetaan harvoin asianomaisten laitosten tietoon tai sitten ne julkaistaan maneereja vilisevällä tieteellisellä slangilla, mistä on seurauksena, että aikuiskasvatuksen parissa työskentelevät kokevat joutuneensa vain palvelemaan tutkijoiden omaa urakehitystä,

1) tutkimuksia ei koordinoida ja tästä johtuen monet ongelmat otetaan esille useaan kertaan,

m) valtaosa tutkimuksista pyrkii käsittelemään kasvatuksen 'heikkoja kohtia', jotka jo ovat sen piirissä työskentelevien tiedossa - ja he puolestaan eivät välttämättä ole kiinnostuneita näiden 'heikkojen kohtien' tuomisesta julkisuuteen,

n) useat tutkimusprojektit ovat niin kalliita, että esitettävien tulosten on oltava vaikuttavia kaiken uhalla, jopa senkin ettei niillä ole juurikaan arvoa käytännön kannalta.

Tekemäni kansalaisopistojen (Volkshochschule) opettajien haastattelut vahvistavat sen, ettei tutkijoiden ja aikuiskasvattajien väliselle luottamukselle ja solidaarisuudelle ole luotu perustaa. Useinkaan ei luoteta siihen, että molemmat osapuolet olisivat kiinnostuneita kehittämään kasvatusta tässä ja nyt sen 'asiakkaiden' parhaaksi. "'Monenlaisten eri kokemusten ten vuoksi aikuisopiskelijoiden parissa suoritettavaa kyselytutkimusta tai heidän havainnointiaan tuetaan vain, kun sen valmistelu ja toteutus tapahtuu yhdessä opettajakunnan kanssa ja se nivelletään kyseisen kurssin omak- sumaan kasvatuskäsitykseen." (Schäffner 1977, 191) Tutkimuksen suunnittelua yksissä tuumin on yritetty monta kertaa. Se, että tällöin on usein epäonnistuttu, ei ole johtunut haluttomuudesta toimia yhteistyössä vaan siitä, että aikuiskasvattajilla on ollut riittämättömästi aikaa ja että keskimääräisessä viestinnässä on esiintynyt ongelmia.

Muut opetuksen tutkimukseen liittyvät vaikeudet aiheutuvat aikuiskasvatustieteen kehityksestä ja nykytilasta. Tutkimuksella ei ole sellaista perinnettä, jonka pohjalta se voisi toimia edelleen, vaikka kouluopetuksen tutkimuksen juuret ovat löydettävissä jo 18. vuosisadalta. Muistakaan maista ei löydy juuri lainkaan sellaisia tutkimusprojekteja, joista voitaisiin ottaa käyttöön sopivia menetelmiä; N.L. Gage'n laajassa kasvatustutkimuksen käsikirjassa puhutaan tuskin ollenkaan aikuiskasvatustutkimuksesta. Kouluopetustutkimisessa käytettävien menetelmien soveltaminen on mahdollista vain rajoitetusti siitä syytä, että valtaosa tehdyistä tutkimuksista - joita useimmat ovt amerikkalaisia - lähtee liikkeelle opettaja-oppilassuhteesta ja pohjautuu ärsy$\mathrm{ke} /$ reaktio-oppimiskäsitykseen. Lisäksi usein riittävän objektiiviset, luotettavat ja pätevätkin havainnointikeinot kykenevät kartoittamaan vain sellaisia yksiselitteisiä, irrallisia, yksittäisiä ilmiöitä kuin esim. 'opettajan hymy'. Voidaksemme ottaa tutkimuksen piiriin sellaisia vaikeita asiakokonaisuuksia kuin motivaatio tai jonkin tietyn toimenpiteen merkitys käytännön opetustyössä me tarvitsisimme kuitenkin parempia havainnoinnin kategorioita ja välineitä. Itse asiassa ainoastaan hyvin harvoissa tapauksissa opetuksen havainnointi täyttää vaatimuksen, että sen tulee olla opetuksen sisällön kannalta relevanttia.

Tähän saakka aikuiskasvatuksen empiiristä tutkimusta ovat suorittaneet ensi sijassa sosiologit ja psykologit. Ne harvat kasvatustieteilijät, jotka 1960-luvulla harjoittivat aikuiskasvatukseen liittyvää tutkimus- ja opetustoimintaa, eivät olleet muista velvoitteistaan johtuen kykeneviä tarttumaan aikaavievään opetustutkimukseen. Niissä tapauksissa, joissa havainnointia on suoritettu, se on tapahtunut yleensä sosiaalipsykologian tai ryhmädynamiikan näkökulmasta. Valtaosa suoritetuista tutkimuksista on intekratioanalyysejä. Opetuksen ja oppimisen sisältöön liittyviä ongelmia on laiminlyöty sillä seurauksella, että jo saaduista tutkimustuloksista on vain vähän hyötyä, opetusmenetelmien suunnittelussa. "Jos suunnitteluun avuksi etsitään empiiristä tietoa, sitä on saatavissa pääasiassa joko sosiobiografisen ai- 
neiston tai työntekijän työtilanteen kuvausten muodossa. Tämä tieto ei kuitenkaan liity oppimisprosessiin eikä siihen, mitä muutoksia tietosisällössä tapahtuu, kun se välitetään opiskelijalle."' (Tietgens 1977, 19)

Iskulause "suunta kohti realismia" ei siis merkitse samaa aikuiskasvatuksessa kuin kouluopetuksessa. Jälkimmäisessä se on tarkoittanut tutkimusmenetelmän ja tieteellisen teorian kohdalla siirtymistä tulkinnallisuudesta empiirisyyteen, "pedagogiikasta kasvatustieteeksi", (Brezinka); aikuiskasvatuksesta em. iskulause viittaa pikemminkin yleisen koulutuspolitiikan mukaisen organisoidun ja ammatillisesti relevantin opiskelun lisääntymiseen suuntaviivojen mukaisesti eikä niinkään mihinkään opetusmenetelmien merkittävään empiiriseen tutkimiseen. Kasvatustutkimuksen osana toteutettu evaluaatio- ja tehokkuustutkimuskaan ei ole poistanut tätä puutetta, sillä ei ole pystytty luotettavasti osoittamaan, tulevatko yhteiskunnallista koulutusta antavien oppilaitosten opiskelijat kriittisemmäksi ja itsekriittisemmiksi, vai vahvistuvatko heidän omat ennakkoasenteensa entisestään.

Vielä muutama vuosi sitten katsottiin yleisesti, että aikuiskasvatustutkimuksessa tulisi antaa etusija opetustutkimukselle. Sittemmin on kuitenkin lisääntyvässä määrin esiintynyt näkemyksiä, joiden mukaan aikuiskasvatuksen yhteiskunnallis-taloudellisiin puitteisiin ja kultturellisiin puitteisiin liittyvän tutkimuksen tulisi olla ensisijalla samalla kun on todettu, että jokainen opetus-oppimisprosessien yksityiskohtainen erittely jättää huomiotta kysymyksen kasvatuksen yhteiskunnallisesta tehtävästä ja merkityksestä.

\section{Aikuisopetustutkimuksen menetelmiä ja tuloksia}

Opetustutkimuksen piiriin kuuluviksi katsotaan tässä sellaiset tutkimukset, jotka kokoavat, erittelevät ja arvioivat aikuisten opetusoppimisprosesseja käyttäen apunaan erilaisia havainnointimenetelmiä, arviointiasteikkoja, sisältöanalyysejä tai koejärjestelyjä. Seuraavassa esimerkkejä näitä menetelmiä käyttävistä tutkimuksista.

Tällä tutkimusalueella eniten käytetty tiedonhankintatapa on kirjalliset kyselyt osallistujille, koska vastausten käsittely on suhteellisen ongelmatonta. Menetelmän haittana on se, että kysymykset määräävät usein jo ennalta vastausten sisällön ja että ei olla tekemisissä itse opetuksen, vaan opiskelijoiden siitä muodos- taman tulkinnan kanssa. Toisaalta voidaan myös todeta, että tietylle kurssille osallistuvien opiskelijoiden subjektiivinen näkemys kurssistaan on aivan yhtä huomionarvoinen kuin niin sanotuin objektiivisin menetelmin kurssin etenemisestä saatavat tiedot. Sillä, onko luennoitsija opiskelijan mielestä ystävällinen vai ei, on merkitystä hänen tulevalle opiskelulleen kyseisellä kurssilla riippumatta siitä, onko hänen saamansa vaikutelma perusteltu vai ei.

Tällaisten opiskelijoihin kohdistuneiden kyselyjen tuloksia julkaistaan usein, kun taas systemaattiseen havainnointiin perustuvia tutkimusraportteja on tuskin lainkaan saatavissa. Havainnointia suoritetaan aika ajoin, mutta on ilmeistä, että sen tulokset vain harvoin ovat julkaisukelpoisia tai sellaisia, että niiden paikkansapitävyys olisi edes osin vahvistettu, mikä puolestaan johtuu edellä kuvatuista vaikeuksista. Vaikka on olemassa huomattava määrä vuorovaikutusongelmia ja ryhmäprosesseja käsittelevää kirjallisuutta, vastaavat empiiriset tutkimukset ovat harvalukuisia. Melko ongelmatonta on sellainen havainnointi, joka pyrkii ainoastaan tuottamaan sosiogrammoja ja kuvauksia opetuksessa mukana olevista. Niin pian kuin opetuksen sisältöä pyritään muistiin merkitsemisen ohella myös luokittelemaan, herää kysymys asianmukaisista kategorioista, joiden tulee olla yhtäpitäviä (eli selkeästi yhdellä ja samalla tasolla), joiden tulee myös olla siten operationalisoituja, että ne ovat yksittäisinä tunnistettavissa, ja joiden tulee olla luotettavia, valideja ja objektiivisia jne. Lisäksi havainnointijärjestelyn tulee olla toteutuskelpoinen ja itse havainnoinnin tulee tapahtua niin, että se aiheuttaa opetukselle niin vähän häiriötä kuin mahdollista.

Havainnointimenetelmä, joka (aistihavainnoinnin valikoivuuden kielteisistä vaikutuksista huolimatta) mahdollisimman objektiivisesti pyrkii merkitsemään muistiin opiskeluryhmissä tapahtuvan kuuloon perustuvan ja nonverbaalisen kommunikaation, tulisi selvästi erottaa sellaisista arviointimenetelmistä, joissa tulokset arvioidaan jälkikäteen mittausasteikon avulla ja se siis perustuu harkintaan tai spontaaniin vaikutelmapohjaiseen uudelleenarviointiin. "'Jos vaikutelma-asteikkoihin perustuvia menettelytapoja käytetään, on selvää, että arvioija on itse mittaväline, jos taas havainnointimenetelmä on käytössä, kysymys on luokittelujärjestelmästä havainnointia koskevine ohjeineen." (Schelten 1976, 198). Koska tuskin on mahdollista luoda henkilöidenvälistä tarkistusjärjestelmää, monet empiirikot suhtautuvat tällaisiin arviointimenetelmiin epäil- 
len ja niitä käytetään harvoin ainoana tutkimusmenetelmänä. Useimmiten niiden tehtävänä on täydentää havainnointia ja kyselytutkimusta. Edelleen voidaan erottaa toisistaan sellainen tutkimus, jossa havainnoija itse suorittaa arvioinnin ja sellainen, jossa joko opiskelijat tai opettajat täyttävät asteikot.

Havainnoinnin tapahtuessa luokassa, tutkijan täytyy omata huomattavasti identifiointija järjestelykykyä. Hän ei koskaan kykene ottamaan talteen "aitoa todellisuutta" vaan ainoastaan omat havaintonsa siitä, mitä tapahtuu. Hänen päätelmiään voidaan tuskin alistaa henkilöidenväliseen tarkistukseen, koska se, mistä hän on havaintonsa tehnyt, ei ole toistettavissa. Tähän liittyvät ongelmat häviävät osittain silloin, kun opetusyksiköitä äänitetään nauhalle tai kuvataan videokasetille. Tällöinkin otokset edustavat vain yhtä tiettyä näkökulmaa, mutta ne voidaan evaluoida useammin kuin kerran ja myös eri henkiöiden toimesta. Tämä menetelmä mahdollistaa erityisesti opetusotosten sisällön erittelyn. Jo edellä kävi ilmi, että vain harvoin ääninauhoja ja videokasetteja voidaan valmistaa kansalaisopistoissa ja muissa vastaavankaltaisissa laitoksissa.

Opetustutkimuksen kaikkein kallein muoto on tavallisesti kokeellinen testaus. Tällä en tarkoita niinkään behaviorististyyppistä laboratoriotutkimusta, joka on yleisessä käytössä luonnontieteissä, mutta tuskin toteutettavissa saksalaisen aikuiskasvatuksen piirissä, vaan pikemminkin kvasiempiirisiä malliseminaareja arkipäivän olosuhteissa, joissa kuitenkin voidaan verrata toisiinsa testi- ja kontrolliryhmiä opetusmenetelmien eri muuttujien vaikutuksen todentamiseksi.

\section{Opetus- ja oppimisprosessit aikuiskasvatuksessa}

Seuraavassa tarkastellaan yksityiskohtaisesti erästä monivaiheista projektia, jonka organisoi Niedersacksenin pedagogisen korkeakoulun Hannoverin osaston (nyk. Hannoverin yliopisto) aikuiskasvatuksen professori. Tutkijaryhmä koostui professorin kuudesta kollegasta ja tutkimusaiheena olivat ne humanististen aineiden ja yhteiskuntatieteiden kurssit, jotka sopivat nimikkeen 'yhteiskunnallis-kultturellinen' aikuiskasvatus alle. Opetus- ja oppimisprosessien tutkimista varten asetettiin seuraavat kriteerit:

Opetus-oppimistutkimuksen oli määrä:

1. tutkia opetus-oppimisprosesseja luokkaopetustilanteessa
2. ottaa huomioon ja kytkeä toisiinsa opettajien ja oppilaiden ominaisuudet ja toiminnot

3. tulkita opetus- ja oppimisprosessissa esiintyviä yksilöllisiä eroja, joita havaitaan erilaisten luonteenpiirteiden omaavien henkilöiden välillä

4. pyrkiä ymmärtämään, mitkä ovat opetus-oppimisprosesseissa toisaalta niiden affektiiviset ja toisaalta kognitiiviset tekijät

5. ottaa mukaan tarkasteluun opetuksen sisältö

6. antaa lisävalaistusta opetusmuuttujien interaktiovaikutuksista

7. tutkia opetusta prosessina

8. ja hakea sille pohjaa teorioista

9. pyrkiä korkeatasoiseen empiiriseen metodologiaan

10. pohtia, mitä käytännön merkitystä opetukselle tuloksilla voisi olla.

Tällainen tutkimus vaatii useiden tutkimusmenetelmien yhdistämistä, koska yhden menetelmän avulla tuskin saadaan tuloksia minkään alan opetuksessa. Niinpä esimerkiksi yhden ihmisen opetuskäyttäytymisen havainnointi ei itsessään ole paljastavaa. Se on sitä vain suhteessa opiskelijoiden tyytyväisyyteen tai edistymiseen ja ne on puolestaan mitattava kyselykaavakkeen tai testin avulla. Sille, mitä havainnoidaan, voidaan yleensä antaa enemmän kuin yksi tulkinta, siksipä - jos halutaan saada mahdollisimman selkeitä selityksiä - lisätiedot ovat tarpeen. Esimerkiksi jos päämääränä on vain laatia luettelonomainen kuvaus opetus-oppimisprosesseista, täytyy jo ennen tutkimussuunnitelman tekemistä olla olemassa tietty teoreettinen perusta esitettäville kysymyksille ja tietoa tuottavalle tutkimusintressille. Tässä nimenomaisessa tutkimuksessa pääasiallinen tavoite oli tutkia opiskelijoiden osallistumista opetusmenetelmiä koskevaan päätöksentekoon.

Useista havainnointitavoista ja kyselymenetelmistä käsitellään tässä vain " proseduuripöytäkirjaa"'. Kaikki sekä opettajien että opiskelijoiden puhumalla ilmaisemat lausumat luokiteltiin muutamaksi laajaksi kategoriaksi siten, että huomio kohdistui enemmänkin kyseisten lausumien didaktiseen kuin sosiaalipsykologiseen funktioon. Tällä proseduuripöytäkirjalla pyrittiin erityisesti osoittamaan, missä määrin opiskelijat ottivat osaa kurssin läpiviemiseen; tästä johtuen tehtiin myös ero oppiainetta ja menettelytapoja koskevien lausumien välillä. Useimpien kouluopetustutkimusten voidaan todeta havainnointimalleissaan ryhmittävän opettajien ilmaisut kuuluviksi 'virikekategorioihin' (kysymykset, ohjanta) ja oppilaiden kuuluviksi 'reaktiokategorioihin' (vastaukset, tottelevaisuus, reagointi, ärsykkeisiin). Tutkimuksessamme käytettiin kuitenkin samoja ka- 
tegorioita sekä opettajien että oppilaiden kohdalla, jottemme heti alun alkaen olisi sulkeneet pois mahdollista roolienvaihtoa opettajan ja opetettavan välillä.

Pitkään kestäneen alustavan testauksen jälkeen muodostimme kahdeksan kategoriaa, joihin miltei kaikki lausumat mahtuvat ja jotka ovat osoittautuneet suhteellisen objektiivisiksi ja luotettaviksi. Yhteensä 120 yksiköstä luokanopetusta kirjattiin muistiin 11608 lausumaa (mikä merkitsee keskimäärin 97,5 lausumaa jokaista 90 minuutin pituista periodia kohti) ja nämä lausumat jakautuivat kahdeksaan kategoriaan seuraavalla tavalla:

Oppiaineeseen liittyvät

Informaatio (I.N.F.) 33,5\%

Tulkinta (I.N.T.) $31,9 \%$

Tietoa haluava kysymys (Q) 10,8 \%

Tulkintaa kaipaava kysymys (QT) 7,1 \%

\section{Menettelytapoihin liittyvät \\ Virike (S) 6,9\% \\ Vahvistus (C) 6,5\% \\ Toisto (R) $1,6 \%$ \\ Yhteenveto (SU) 1,5\%}

Havainnoijan tuli lausumien luokittelun ohella myös identifioida puhuja numeroimalla oppilaat koodein $\mathrm{T}_{1}-\mathrm{T}_{8}$ heidän istumapaikastaan riippuen. (Koska opiskelijat kuitenkin usein vaihtoivat paikkaansa, tietyn opiskelijan koko kurssia koskevan osallistumisen rekonstruointi oli mahdollista vain poikkeustapauksissa). Edelleen havainnoijan tuli arvioida lausumien kesto. Pöytäkirjan sivun yhden sarakkeen oli määrä merkitä 30 sekuntia.

Pöytäkirjan merkinnöistä käy ilmi yksittäisen tunnin ja jopa koko kurssin kulku. Havaittiin, että jokaisella opettajalla oli oma suhteellisen muuttumaton tapansa hoitaa iltaopetuksensa; niinpä riittikin yleensä, että havainnoitiin vain kolmea opetusyksikköä kultakin kurssilta. Edelleen havaittiin, että enemmistö opettajista puhuu useammin ja pidempään kuin kaikki opiskelijat yhteensä ja että valtaosa henkilökunnan jäsenistä pitää itseään asiantuntijoina. Useimpien opiskelijoiden ensisijainen kiinnostuksen kohde on tiedonhankinta, sillä enemmistö heidän tekemistään kysymyksistä pyrkii hankkimaan tietoa, kun taas opettajat haluaisivat mieluummin saada opiskelijat pohtimaan oppiainetta ja käyttävät siinä apunaan tulkinnallisia kysymyksiä. Opiskelijoilla on tuskin osaa siihen millä tavoin tunti etenee: useimmat virike- ja vahvistuslausumat tulevat opettajalta. Vain hyvin harvoin ryhmässä tapahtuu. keskustelua ilman opettajan minkäänlaista puuttumista siihen; yleensä oppilaan lausumaa seuraa opettajan kannanotto.
Eri kurssien vertailu on usein mielenkiintoisempaa kuin tällaiset keskiarvot; on mahdollista erottaa tyypillisiä kurssiprofiileja. On kuitenkin myönnettävä, että nämä tiedot tuottavat opetusmenetelmien kannalta relevantteja johtopäätöksiä vain, jos niitä täydentävät muut havainnoidun käyttäytymisen syitä ja tarkoitusperiä koskevat tosiasiat. Havainnoinnin tulokset antavat aiheen olettaa, että monet opettajat jättävät huomiotta opiskelijoiden piilevän kiinnostuksen osallistumiseen. Kyselytekniikka on kuitenkin kyennyt paljastamaan opiskelijoiden keskuudessa monenlaista ja osin ambivalenttiakin suhtautumista siihen, että opiskelijalla olisi sananvaltaa päätettäessä hänen opintojensa luonteesta. Naiset, vanhemmat henkilöt ja vähän kouluja käyneet opiskelijat pelkäävät, että itsensä ilmaisussa heitä taitavammat nuoremmat opiskelijat dominoisivat heitä ja niinpä he odottavat opettajan ajavan heidän etuaan. Toisaalta havainnoinnin kautta saadun tiedon vertaaminen kyselytuloksiin paljastaa, että keskiarvoa suurempi määrä opiskelijoita oli tyytyväisiä useampiin sellaisiin kursseihin, joilla etenemiseen liittyviä lausumia saatettiin usein merkitä muistiin.

Kaikki tutkimustulokset eivät ole vielä saatavissa. Monia tulkintoja ei ole riittävässä määrin tarkistettu empiirisesti. Useissa kohdin muiden tutkimusten tulokset saivat lisätukea, esimerkiksi: opettajakunnan opetusaineeseen suuntautuva orientoitumistapa iltakursseilla; palautteen antamista ja sellaisten keinojen käyttöä, joilla opintojen eteneminen voidaan varmistaa, lyötiin laimin; sen ajan kestoa aliarvioitiin, jonka opettajakunta käyttää luokalle puhumiseen; miellyttävän, painostuksesta vapaan ilmapiirin luomista vähäteltiin eritoten sellaisilla kursseilla, joihin ei kuulu kokeita; teknisten apuvälineiden tai aktivoivien työtapojen, kuten roolileikin ja case study-tyyppisen erittelyn, vähäinen käyttö; opitun soveltaminen opiskelijoiden elämän eri toimintoihin oli melko harvinaista; useimpien opiskelijoiden, erityisesti vanhempien henkilöiden, naisten ja varhain päätoimisen opiskelun lopettaneiden hämmästyttävän suuri tyytyväisyys; vanhempien opiskelijoiden huomattavan suuri takertuminen opettajakuntaan; yhteisöön liittyvien emotionaalisten tarpeiden suuri merkitys; opintojen tavoitteita koskevan keskustelun kokeminen pelkkänä rituaalina; ja negatiivinen korrelaatio välitetyn tosiasiatiedon ja opintomenestyksen välillä.

Toiset tulokset olivat odottamattomia. Esimerkiksi kun vain vähän koulutusta saaneiden 
opiskelijoiden joukossa alunpitäen vallinneet osallistumisesteet oli voitettu, heidän osallistumisensa oli säännöllisempää ja he valmistautuivat intensiivisemmin kurssitapahtumiin kuin oli laita pitkälle koulutettujen kohdalla. Vähän koulutusta saaneet opiskelijat tarkistivat ja korjasivat näkemyksiään useammin kuin pitkälle koulutetut. Vaikka kaikkien opiskelijoiden akvitoituminen on toivottavaa, osallistumisen ja toisaalta tyytyväisyyden ja koetun opintomenestyksen välillä ei havaittu positiivista korrelaatiota. Vaikkakin monet kysymykset kaipaavat vielä selvitystä, oli mahdollista vahvistaa koejärjestelyjen avulla ja muutamin varauksin se hypoteesi, että keskustelu opintotavoitteista sekä niiden formulointi ja luokitus parantavat oppimista ja lisäävät tyytyväisyyttä kurssiin. Siihen ovatko opiskelijat oppineet ja miten tämä tutkimus ei anna lopullista vastausta, koska oppimisprosessit eivät ole havainnoitavissa. Korkeintaan havainnointi voi kirjata osoituksia menestyksekkäistä opintosuorituksista. Tämän kysymyksen selvittäminen vaatiikin lisätutkimusta. Mitä hyötyä on muodollisesta oppimisesta aloilla, joilla käytännön tehtävät ovat etusijalla? Mitä etua on kokemusten pohdinnasta tai informaation jakamisesta? Milloin on mahdollista ja paikallaan oppia keksimisen kautta ja milloin älyllisen vastaanottamisen kautta?

Kysymykseen, auttavatko nämä tutkimukset meitä osaltaan uudistamaan opetusmenetelmiä, ei voida antaa yleispätevää vastausta; sen saaminen edellyttää tehokkuuteen kohdistuvien lisäkontrollitutkimusten suorittamista. Voidaan otaksua ettei juuri kukaan opettaja muuta käyttäytymistään nämä tutkimustulokset luettuaan tai edes suhtautumistaan aikuisopetukseen. Tutkimuksen vaikutus kohdistuukin käytännössä erityisesti siinä aktiivisesti mukana olleisiin henkilöihin, joiden kanssa yhdessä tulokset on tulkittu. Tällaiseen yhteistyöhön pääsimme asiasta kiinnostuneiden kollegojen kanssa aika ajoin, sitä ei kuitenkaan tapahtunut suuressa mittakaavassa.

Näiden tutkimusten jatkoa suunnitellessamme yritämme kiinnittää huomiotamme pedagogista toimintatutkimusta koskevaan keskusteluun; näiden ensi yritysten olisi löydettävä tiensä myös aikuiskasvatustutkimuksen piiriin. Epäilemättä klassilliseen empiiriseen tutkimukseen kohdistuva kritiikki pätee - muutamin varauksin - myös meidän tapauksessamme. Jotkut kyseisistä puutteista ja vioista tullaan poistamaan tutkimukseemme liittyvällä projektilla, joka pyrkii yhdistämään tutkimuksen oppimiseen ja opetussuunnitelmaan:
1. Tähän saakka kysymysten ja havainnoinnin kohteena ovat olleet opiskelijat, joiden kohdalla sosialisaatio-odotukset ovat suhteellisen myönteiset. Lähestyttävien henkilöiden piiriä tullaan laajentamaan.

a) Mukaan otetaan kasvatuksellisesti muita heikommassa asemassa olevia ja heitä koskevat erityisjärjestelyt, ts. keskiasteen koulutuksen päättämiseen valmentavat kurssit ja opintovaiheiden aikana pidettävät seminaarit.

b) Lisäksi henkilöiltä, jotka eivät osallistu aikuiskoulutukseen, tullaan kysymään, miksi he eivät osallistu.

Ilmeisesti tällä tavoin on mahdollista ymmärtää oppimiskäyttäytymisen yhteiskunnallistaloudelliset ja -kulttuurilliset determinantit tarkemmin kuin mitä ensimmäisessä projektissamme tapahtui ja myös tulkita asianmukaisemmin kurssien havainnoinnin kautta saatua tietoa.

2. Standardoituja kirjallisia kysymyksiä ja standardoitua havainnointia täydennetään haastatteluin ja oppiainetta koskevin pöytäkirjamerkinnöin. Yrityksemme rekostruoida saamastamme aineistosta yksilöllisiä oppimisprofiileja ja -prosesseja oli varsin kallista ja onnistui vain osittain, koska käyttäytymismallien selittäminen ei yleensä ollut mahdollista ilman keskustelua opiskelijoiden kanssa. Nyt havainnoinnin ja kyselytutkimuksen tuloksia aiotaan pohtia ja tulkita opiskelijoiden ja opettajien kanssa viivytyksettä.

3. Alustavat kyselymme oli suoritettu kursseilla, joilla opiskeltiin eri oppiaineita ja suurelta osin ne olivat taipuvaisia jättämään huomiotta opiskelijoiden kiinnostuksen oppiaineeseen. Sen sijaan nyt tullaan opiskelijoiden henkilötietoja koskevan erittelyn avulla pyrkimään siihen, että heidän ammatillisesta, poliittisesta ja yksityiselämästään saadun tiedon perusteella todettaan heidän oppimismahdollisuutensa ja -potentiaalinsa, jotka puolestaan otetaan huomioon suunniteltaessa opetusta keskiasteen koulutuksen päättämiseen valmentavilla kursseilla ja opintovapaan aikana pidettävissä seminaareissa. Samalla tulemme tutkimaan missä määrin arkipäivän tieto, kokemus ja tulkintamallit ovat tärkeitä opetukselle.

4. Käytävät keskustelut tulevat samalla auttamaan opintoneuvonnan antamisessa oppilaille ja heidän oppimisintressiensä määrittämisessä selkeästi. Tästä seuraa, että vaikutus pedagogiikan kenttään toimintatutkimuksen alalla on suora ja että haastattelijan perinteinen välimatka työhönsä katoaa. Keskusteluihin tulevat osallistumaan oppilaitosten henkilökuntaan kuuluvat ja tutkimusryhmän jäsenet.

5. Haastattelujen tuloksia tullaan käyttämään 'didaktisena raaka-aineena'; havainnoinnin tulosten evaluointi tapahtuu yhteydessä opetusprosessiin ja opetussuunnitelmakäsitteen uudelleenarviointiin. Näin voidaan ainakin jossain määrin päästä aikaisemmille tutkimusprojekteille luonteenomaisesta opetustutkimuksen, evaluaation ja opetussuunnitelmien tarkastelun erottamisesta toisistaan. 
6. Kaikissa aiemmissa tutkimuksissamme olemme keskittyneet iltaoppilaitosten kursseihin. Nyt aiomme tutkia voiko eri opiskelupaikkojen (kunnallinen elokuvateatteri, vapaa-ajanviettoon tarkoitettu motelli, ammatinvalinnanohjauskeskus) yhdistäminen luoda oppimismotivaatiota opiskeluun tottumattomien aikuisten piirissä.

7. Joihinkin keskiasteen koulutuksen päättämiseen tähtäävien kurssien oppiaineisiin ja opintovapaan aikana pidettäviin seminaareihin kehitellään parhaillaan uusia opetussuunnitelmia, joita evaluoidaan koe- ja kontrolliryhmissä. Seurauksena tästä on, että opetustutkimus on muuttumassa käytännöllisempään suuntaan, se tullaan suhteuttamaan erityisopetukseen ja tiettyihin kohderyhmiin, kuten monet aikuiskasvatuksen parissa työskentelevät oikeutetusti ovat vaatineet.

8. Ensimmäisessä projektissamme opintomenestyksen arvioivat opiskelijat. Uuden tutkimuksemme tuloksiin sisällytetään joitakin oppiaineita koskevan proseduuriarvionnin ohella myös 'tuotosevaluaatiota'. Tämän ohella kurssien lopussa pyritään sekä tutkimaan opintomenestyksen joitakin ulottuvuuksia koe- ja kontrolliryhmissä että arvioimaan keskiasteen koulutuksen päättämiseen valmentavien kurssien ja opintovapaan aikana pidettyjen kurssien pitkän aikavälin vaikutuksia ko. kurssien lopussa. Tähän mennessä ei tämäntyyppisiä tehokkuustutkimuksia liene systemaattisesti suoritettu aikuiskasvatuksen piirissä kokopäiväistä opetusta antavien koulujen ulkopuolella.

\section{Lähteet}

Feig, R.: Motivationsstrukturen in der Erwachsenenbildung (Motivation structures in Adult Education), Bern 1972.

Hasselhorn, M. and E. Niehuis: Politische Erwachsenenbildung in Landgemeinden (Political Education for Adults in Rural Communities), Heidelberg 1976.

Jagenlauf, M. and H. Siebert: Die Volkshochschule im Urteil ihrer Mitarbeiter (The Folk High School as judged by its Teaching Staff), Brunswick 1970.

Lempert, W.: Aufgaben der Berufsbildungsforschung (Tasks of Research into Vocational Education), in Zeitschrift für Pädagogie 22 (1976), pp. 5776.

Mader, W. and A. Weymann: Erwachsenenbildung (Adult Education), Bad Heilbrunn 1975.

Schäffner, L.: Empirische Untersuchungen in der Erwachsenenbildung (Empirical Investigations in Adult Education), in Siebert 1977, pp. 184208.

Schelten, A.: Beobachtung und Rating in der Unterrichtsforschung (Observation and Rating in Research into Teaching), in Pädagogische Rundschau 30 (1976), pp. 196-200.

Siebert, H. (ed.): Praxis und Forschung der Erwachsenenbildung (Adult Education in Research and Practice), Oplacien 1977.

Siebert, H. and H. Gerl: Lehr- und Lernverhalten bei Erwachsenen (Teaching and Learning Behaviour in Adults), Brunswick 1975.

Tietgens, H.: Forschung in der Erwachsenenbildung (Research into Adult Education), in Siebert 1977, pp. 11-28. 